\title{
Plutarch on the Role of Eros in a Marriage
}

\author{
Jeffrey Beneker
}

Plutarch's thinking on marital relationships has attracted a significant amount of interest in recent years and has been approached from a variety of perspectives. Some scholars have studied the societal aspect of marriage in Plutarch's works, raising questions about the role of women in the household, in the community, and especially in their interactions with men, and therefore they have tended to address larger social issues, such as gender, sexuality, and equality. ${ }^{1}$ Others have taken a philosophical tack and have examined Plutarch's writing, especially as it concerns the nature and value of marriage, in terms of the broader philosophical traditions to which it is related. ${ }^{2}$ However, my focus in this paper is much more narrow. I intend to explore one particular component of the marital relationship itself: the erotic connection that exists, or might exist, between a husband and wife. Looking first to the Moralia and the dialogue Amatorius, I will argue that Plutarch describes the eros shared between a married couple as an essential prerequisite for the development of philia and virtue. Then, turning to the Lives, I will demonstrate how the ideas found in the Amatorius are fundamental to Plutarch's representation of marriage in the biographies of Brutus and Pompey.

In the Amatorius, Plutarch, who is himself the principal speaker, touches on a variety of topics related to eros, but the discussion itself is motivated by a single event: the wealthy widow Ismenodora has expressed her desire to marry the ephebe Bacchon, who comes from a family of lower social standing. Most of their fellow citizens oppose the marriage, and Plutarch makes his friends Protogenes and Zeuxippus voice the principal arguments against it. Their attacks give Plutarch the opportunity to make a multifaceted response. Two particular charges allow him to speak directly to the institution of marriage and the role of eros, and his responses will form the basis of our discussion.

One of the opposing party's objections stems from the belief that a marriage must be contracted at the proper time. While the discussion that ensues is only tangentially related to eros, it does introduce ideas that are fundamental to Plutarch's view of marriage and which lay the groundwork for his introduction of erotic elements. Protogenes takes offense at the inversion of

1 E.g. McInerney, Nikolaidis, Pomeroy, and Walcot. See also the discussions in Blomqvist, 73-74, and Whitmarsh.

2 E.g. Brenk 1988 and 2000, Crawford, Goldhill, Martin 1978, Rist, and Wohl. 
ages in the proposed union $(753 a-b)$, quoting from Hesiod in order to demonstrate the proper "season" for marriage:

When a man has passed not much more than thirty years and hasn't gone too far

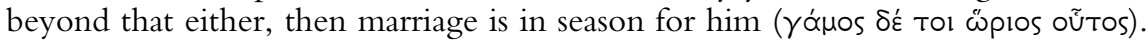
And let the woman be in her prime for four years; then let her marry in the fifth (753a $=$ Works and Days 696-98).

If the usual roles are reversed, then Ismenodora must be about thirty years old, and Bacchon seventeen or eighteen. ${ }^{3}$ Plutarch's counter argument does not challenge Hesiod's rule; he asserts instead that Ismenodora is perhaps more in season than her rivals and sees nothing about her sex that would disqualify her even from being the senior partner. Ismenodora is still young enough to bear children, so the union cannot be challenged on the basis of utility. Moreover, Bacchon, who is called "the beautiful one" (Bók $\chi \omega v l ~ т \tilde{\omega}$ k $\alpha \lambda \tilde{\omega}, 749 \mathrm{c}$ ), has several male erastai, and Ismenodora is older than none of them. Nor, Plutarch adds with a smile, has her hair turned grey like that of some of Bacchon's male lovers: "If these men are consorting with him at the right time, what prevents her from taking better care of the young man than some young woman would?" $(754 \mathrm{c})$. $^{4}$

By this statement, Plutarch adds a second dimension to his rebuttal: Ismenodora is competitive not only with her mature male rivals but with the nubile females as well. He goes on to explain how inexperienced spouses often resist the yoke of marriage:

Young people combine and form a couple with difficulty, putting aside their insolence ${ }^{5}$ and hubris only after much time has passed. In the beginning they seethe and fight the yoke, and even more so if eros is present, for like a wind against a ship with no pilot, it disturbs and confounds the marriage of those who are neither able to lead nor will willing to be led $(754 c-d)$.

Although Plutarch does not draw his conclusion explicitly, his implication is clear: by marrying the older widow Ismenodora, Bacchon would gain a wife who already understands - and would be ready to practice - the cooperation required by marriage. If there is to be an erotic dimension, then this sort of stability will be crucial. Returning to the inversion of ages, Plutarch then observes that no one is truly independent anyway:

3 Puberty for girls was supposed to begin at age thirteen or fourteen; on Hesiod, see West 1978 ad loc.; on Plutarch, see Helmbold, 311 n. a, 331 n. b, and Flacelière 1980, 137, both of whom make reference to Einarson.

4 Cf. Nikolaidis, 80-81.

5 фрú $\gamma$ $\mu \alpha$, translated here as "insolence," is used for the snorting of horses and so adds color to Plutarch's description of the spouses' resistance to the taming required by marriage; see Pelling, 120. 
If the nurse rules the infant and the teacher the boy, if the gymnasiarch rules the adolescent and the erastes the young man, if the law and the general rule a man who has come of age, and so if no one is without a guardian or self-determining,

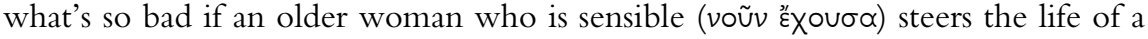
young man, since she'll be beneficial to him because she is wiser, and she'll be

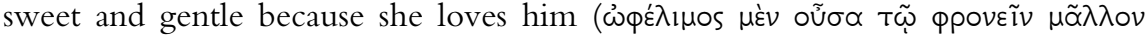

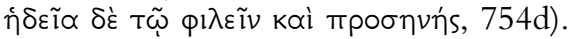

This quotation, and Plutarch's line of reasoning in general, asserts a positive role for a wife who is sensible. However, it would be incorrect to assume that Plutarch would argue for the equality or leadership abilities of women in general. Philip Stadter has written that the women depicted by Plutarch express capabilities in their own way; they do not replace men but instead "display their virtue only where gaps appear in the fundamentally male society," their role being "to support and nourish what is good." ${ }^{\prime}$ Nonetheless, considering the statements quoted above, I believe that Plutarch would still argue that Ismenodora, provided that she is sensible, could make a real, intellectual contribution to the marriage even if Bacchon were more mature. ${ }^{7}$

A second objection to the marriage, directly related to eros this time, is voiced by Protogenes near the start of the dialogue and is taken up again by Zeuxippus. ${ }^{8}$ Protogenes attacked the notion of an eros inspired by a woman, while Zeuxippus appears to have denigrated eros for women by asserting that it made the soul unstable and undisciplined. ${ }^{9}$ Plutarch responds with a vigorous defense, asserting a woman's erotic capability as he had asserted her intellectual capability in his earlier argument: if eros springs from a recognition of true

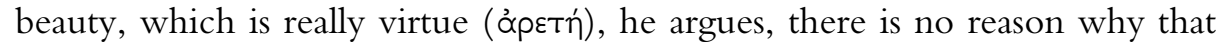
same virtue cannot exist in a woman as well as in a boy (766e-767b). To reinforce his point, he quotes from a play ("Where beauty is present, I am

6 Stadter, 179; see also McNamara, 152-53. In a reading of the Coniugalia praecepta, Wohl argues that a husband demonstrates his own self-mastery by mastering his wife. Wohl might disagree with Stadter's conclusion, I think, by saying that a wife may expose gaps in a husband's virtue but would not be expected by Plutarch to fill them. Nikolaidis, reading the same essay, argues that Plutarch holds husband and wife "equally responsible for the maintenance of a harmonious relationship" (47) but also that a wife must "bow" to her husband's moral superiority (76). See also Blomqvist, 86-87, and Patterson, 134-35.

7 Also significant in this passage is the presence of affection in the form of philia, which I will consider in more detail below.

8 Zeuxippus' speech has been lost in a lacuna (prior to 766e), so we must infer its contents by means of the response it elicits.

9 See Russell, 275-76. Earlier, Protogenes had distinguished between a noble eros for the well-endowed soul of a young man and a base epithumia for women (750d-e). See Rist, 569-70, for the Epicurean underpinning of Zeuxippus' argument. 
ambidextrous," 767a), and he adduces the analogy of horse- and dog-lovers, who appreciate the excellence of animals without regard for their sex.

This line of reasoning might well have been expected, given Plutarch's earlier defense of marriage in terms of a woman's intellectual contribution. However, he carries his point further by arguing for the necessity of eros in a marriage. Zeuxippus, Plutarch says, has been influenced by those who are anerastoi, men who have married either for the sake of a dowry or to produce children. According to Plutarch, the former treat their wives like slaves and accountants, and the latter, having obtained their heirs, allow the marriage to dissolve or, if they remain united, neglect the marriage completely, living together without any erotic attachment $(767 c-d)$. Earlier in the dialogue, when the notion of erotic marriages was directly attacked, Plutarch responded with a criticism that makes his point even more succinctly:

And by Zeus! Pisias is making me an advocate for Daphnaeus when he goes to extremes and applies to marriage an eros-less union, with no share of god-inspired friendship. We observe this union, when erotic persuasion and sexual relations have gone, scarcely to be held together by shame and fear as though by yokes and reins $(752 \mathrm{c}-\mathrm{d}){ }^{10}$

Thus Plutarch characterizes a union conceived and maintained without eros as lacking internal cohesion. ${ }^{11}$

This then is a fundamental principle underlying Plutarch's argument: eros is the agent of true unity between persons. Since he has argued that women as well as men may share in the intellectual and erotic experience, Plutarch is able to postulate a meaningful erotic union for the married couple. Thus he writes: "The saying, 'friends and lovers hold things in common,' is not to be understood generally, but it applies to those who, though divided in body, combine their souls forcefully and meld them together, neither wishing to be two persons nor thinking that they are" (767e). This sort of union is all the more genuine for its internal rather than external origin. As Plutarch explains further, the eros-based marriage results not only in a tightly integrated partnership, but in the ethical improvement of its members as well:

Then there is sophrosyne with respect to each other, which a marriage especially needs. The sophrosyne imposed externally and by laws is compelled by shame and fear rather than willingly, "being the work of many bits and rudders," and is always available to the married couple. But in eros there is enough enkrateia, order, and trust that, if it should ever touch even an intemperate soul, it turns it away from other erastai, cuts short its boldness, breaks its insolence and unmanageability,

10 Pisias is an erastes of Bacchon who argues against the marriage, and Daphnaeus is a companion of Plutarch who takes the side of Anthemion, Bacchon's relative and the marriage's chief proponent.

11 Cf. Crawford, 295-96. 
imports shame, silence, and calm, and dressing the soul in an orderly costume, makes it obedient to one alone (767e).

He will later add, after relating the story of the Galatian Camma's devotion to her husband, that marital eros is the foundation of philia, loving friendship (769a). Thus eros is an essential part of a marriage that is held together by selfcontrol and mutual affection rather than external coercion. ${ }^{12}$ The resulting philia is the sign of that mutual affection and recalls Plutarch's first argument, where he asserted that the wife would treat her husband sweetly and gently because she loved (philein) him. ${ }^{13}$ The virtuous behavior that results from the erotic union is also expressed in terms of the marital union and fidelity. ${ }^{14}$ Carried to its fullest extent, Plutarch's argument, which takes as its starting point the intelligence and virtue of an individual rather than his or her sex, must conclude that the heterosexual, marital union can be ethically fulfilling for both parties.

Turning from the theoretical arguments about Ismenodora and Bacchon, I will consider how Plutarch's assertions transfer to the actual marriages that he describes in two of his biographical works. One of the most colorful women in his Parallel Lives is Porcia, daughter of Cato the Younger and wife of Marcus Brutus. ${ }^{15}$ As Plutarch introduces her in the Life of Brutus, he arranges his description so as to highlight the fact that she is no ordinary wife. In fact, she enters the narrative at a point where Brutus is especially in need of an intelligent, supportive partner and confidant. In chapter 12, Brutus becomes the center of the conspiracy against Caesar, and in the next chapter Plutarch describes the anxiety that results:

Since Brutus had made dependent on himself the first ranks of Rome - men known for their high-mindedness, ancestry, and virtue - and was considering the full risk [of the plot], in public he kept his thoughts to himself and under control, but at home and during the night he was not the same man. Sometimes his worry would wake him involuntarily, and at other times, when he was even more involved in his reckonings and absorbed in his problems, he could not hide from his wife, who shared his bed, the fact that he was filled with an uncustomary turmoil and was pondering within himself some plan that was difficult to bear and to untangle (13.1-2).

12 Cf. McNamara, 157, on the Coniugalia praecepta.

13 See Dover, 209-13, who explains the traditional notion of eros and philia as distinct and independent.

14 Cf. Martin 1984, 83: “One of Eros's two functions as a god is to superintend both the formation of $\phi i \lambda i \alpha$ between lovers and their beloveds, whether the latter be fair youths or virtuous women, and the growth of mutual ápetri that such pi $\lambda \dot{\alpha} \alpha$ produces $(757 \mathrm{~F}-$ 58C, 759A, 765A-66B, 766D-71C)." Cf. also Nikolaidis, 70-71.

15 See Castellani, 146-149, for a list of all the Lives that feature wives who play significant roles in the careers of their husbands. 
Brutus is suffering under the weight of his responsibility and Porcia notices his distress because, significantly, she shares his bed. Her presence in the narrative could have been a literary device: Plutarch might have inserted her as a character in order to observe Brutus' agitation and allow it to be reported. But as the chapter continues, the focus stays with Porcia, giving the reader insight into the nature of Brutus' wife and marriage:

As has been said, Porcia was the daughter of Cato. Brutus, her cousin, did not marry her when she was a virgin but took her after her previous husband had died, while she was still young and already had a small child. The boy's name was Bibulus, and he wrote a small book of memoirs of Brutus, which has been preserved (13.3). ${ }^{16}$

In light of the Amatorius, this passage provides a mixed signal: Porcia is experienced in marriage, like the widow Ismenodora, but she is still young, like the immature wife who, along with her novice husband, must survive the tumultuous early years of a marriage before being tamed. However, as her introduction continues, Plutarch further clarifies her character, allowing the reader to observe that she has overcome her youthful inexperience: "Porcia, who was philosophos ${ }^{17}$ and philandros, and filled with thoughts that were sensible, did not undertake to question her husband about matters that he kept quiet before she performed the following experiment on herself (13.4)." In this passage, Plutarch uses three adjectives that are especially significant in light of the Amatorius. First, Porcia is said to be philosophos and philandros. Both of these terms recall familiar themes: the first is an indication of Porcia's intellectual character, and the second, a compound of philia, shows that she has achieved the loving friendship that follows on eros in the marital relationship. Like Porcia's youth, they are also signs, but in this case they indicate stability rather than volatility. If the representation of this marriage is aligned with the Amatorius, we should expect to observe that the union is based on an erotic attachment and has reached a stage of mutual respect and affection between the partners.

The third adjective is perhaps the most informative. Porcia is said to be

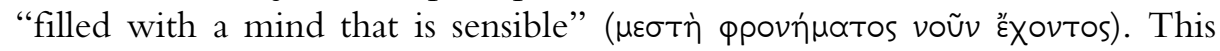
description contains a clear correspondence with the Amatorius: there Plutarch argues that a woman may be a contributing partner in a marriage, provided

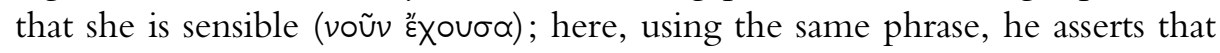
Porcia (or rather, Porcia's mind) possesses that very trait. Clearly she is not

16 At Brut. 2.1, Plutarch explains that Brutus' mother, Servilia, was Cato's sister and that Brutus admired his uncle, who would later become his father-in-law. However, Plutarch does not name or describe Porcia before chapter 13.

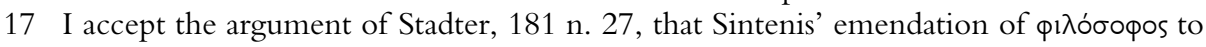

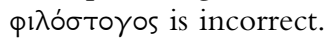


simply the object of sexual desire, and so her presence in Brutus' bed is confirmed as a sign of an intimate relationship.

Plutarch next narrates Porcia's "experiment" and gives to her a speech in which she asserts her own position in the marriage on nearly the same basis as that found in the Amatorius:

She took a small knife (the sort that the barbers use to trim nails) and having driven all of her attendants from her room, she cut a deep gash in her thigh. This produced a great flow of blood, and after a short while, violent pains and feverish trembling resulted from the wound. While Brutus was struggling and angry [because of his anxiety], Porcia, at the height of her pain, spoke to him as follows: "I am the daughter of Cato, and I was married into your household, Brutus, not like the concubines in order to share only your bed and your table, but to be a partner in both good and painful circumstances. Your contribution to our marriage is entirely faultless, but what proof or benefit of my contribution will there be, unless I share in your secret suffering or in your confidential concern? I know that my womanly nature seems too weak to keep a secret, but there is, Brutus, a certain strength of character that comes from a good upbringing and beneficial companionship: it has been granted to me to be the daughter of Cato and the wife of Brutus. Previously I trusted less in these advantages, but now I know that I am even stronger than pain" (13.5-10).

Porcia is compelled to confront Brutus because he does not consent to discuss the conspiracy, which is obviously troubling him, at home. First, however, she must justify her position as a real partner. After withstanding the severe pain of her wound, she calmly addresses her husband, forcefully and logically arguing for her equal standing in their marriage. She begins by insisting that she is not a mere sex object: "I am the daughter of Cato, and I was married into your household, Brutus, not like the concubines in order to share only your bed and your table, but to be a partner in both good and painful circumstances" (13.7). Porcia's statement reveals a distinct contrast between the coerced union and the real marital partnership, between the wife as an object and the wife as a partner in her husband's life. Porcia is claiming to be the latter type, and as such she can provide an on-going benefit and even has a right to be involved in the extra-household life of her husband. She continues by charging that her right is being denied: "Your contribution to the marriage is entirely faultless, but what proof or benefit of my contribution will there be, unless I share in your secret suffering or in your confidential concern?" (13.8).

In making her case, Porcia argues for her ability to play the role she is claiming. She cites the impact of her upbringing and associations, presumably with philosophical types, on her character, and for the second time she invokes her father Cato, adding now the influence of Brutus (13.9-10). Thus she demonstrates the source of a woman's nous (or sense). ${ }^{18}$ She closes her speech

18 Cf. Stadter, 177. 
by admitting that previously even she doubted whether her credentials were adequate. When she exposes the wound and explains her experiment, Brutus' reaction demonstrates without a doubt both the validity of her argument and the quality of her character: "He was dumbstruck, and lifting his hands he prayed that the gods grant that as he completed his mission, he show himself to be a husband worthy of Porcia" (13.11) ${ }^{19}$ Brutus' words and deeds reveal both respect and affection for his wife, a confirmation of her standing and that her philandria is reciprocated.

But was there eros in the relationship? I have conjectured that eros was present because Porcia shared Brutus' bed and because of the mutual philia of the couple, which Plutarch has argued arises from the passion. But if Plutarch was not making that assumption, then the parallelism between this marriage relationship and those described in the Amatorius is diminished. In the final chapter of the Life, however, Plutarch gives evidence for eros as he narrates the deaths of Brutus and Porcia. Having described Brutus' death, he cites Nicolaus of Damascus, who, supported by Valerius Maximus, reports that Porcia in turn committed suicide by swallowing coals (53.5-7). Plutarch notes, however, that there exists a letter of Brutus in which he mentions the death of his wife, thus raising doubts about Nicolaus' chronology. The letter itself might not be genuine, but if it is, Plutarch argues, it provides strong evidence against Nicolaus because it conveys other authentic details: the pathos of Porcia, the manner of her death, and most important for our discussion, her eros for her husband. ${ }^{20}$

It appears, then, that Plutarch has cast the marriage of Brutus and Porcia in the mold of the Amatorius. We may gain an even better perspective on their marriage by comparing it briefly to the marriages of Pompey to Julia and Cornelia, which have an erotic basis but fall just short of the ideal found in the Amatorius. In the Life of Pompey, as Plutarch describes the events of $54 \mathrm{BC}$, when Pompey controlled Spain as proconsul but remained in Rome to dedicate his theater and monitor political events, he claims that political decisions were influenced by an eros for Julia. He writes:

For these things Pompey was admired and loved, but he also attracted a great deal of envy because he handed over his armies and his provinces to legates, who were

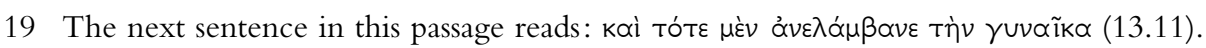
This has been taken by translators to mean that Brutus went to the aid of his suffering wife (Flacelière 1978, Perrin, Scott-Kilvert). However, Philip Stadter has pointed out to me that this meaning of ớ $\alpha \propto \lambda \alpha \mu \beta \alpha^{\prime} v \omega$ does not appear in LSJ and that the sense required here is of Brutus "receiving her into his heart and counsels." Such a reading connects this passage even more closely with the Amatorius.

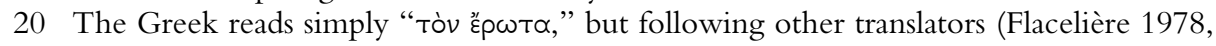
Perrin, Scott-Kilvert), I have supplied the obvious object of the eros that is mentioned by Porcia's husband. 
also his friends, while he traveled here and there, spending his time with his wife in

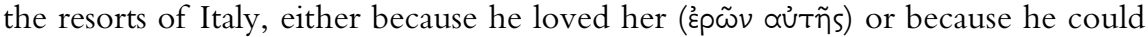

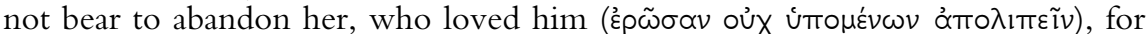
this is also reported. Moreover, the young woman's love for her husband was

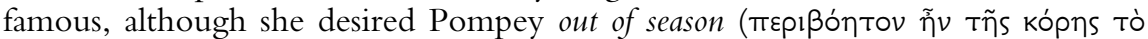

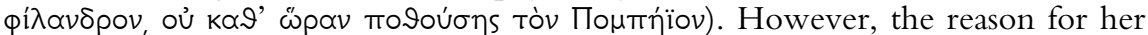
devotion appeared to have been the sophrosyne of her husband, who was intimate with his wife only, and his nobility, which was not excessive, but which made relations pleasant and was especially attractive to women, if Flora the courtesan is not to be convicted of bearing false witness (Pomp. 53.1-2).

This passage contains many elements familiar from the Amatorius and from the marriage of Porcia and Brutus: the mutual eros of husband and wife; the philia that results from the erotic bond; and the virtuous behavior, evidenced by Pompey's sophrosyne. However, there is also an important distinction: Julia

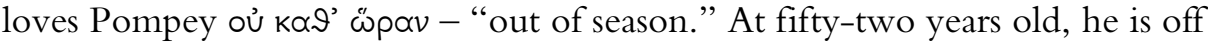
Hesiod's chart, while she, at approximately nineteen years old, is just the right age. $^{21}$ Pompey will find himself in a similar situation with his next spouse, Cornelia. She received an excellent education and has a well trained mind (55.2-3), ${ }^{22}$ but nonetheless Plutarch bluntly remarks that Cornelia would have been a better match for one of Pompey's sons (55.4). And the issue is not simply one of impropriety. Marrying Cornelia “out of season" opens Pompey to criticism on political grounds, as did his marriage to Julia:

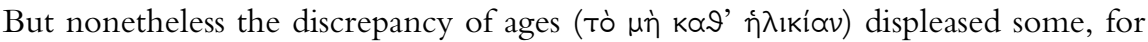

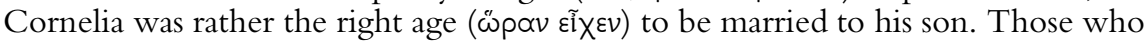
were more insightful thought that Pompey had overlooked the plight of the city while it was in difficult circumstances. They had selected him as its physician and had turned it over to him alone, but he was putting on garlands and celebrating his marriage, while he ought to have considered the [solo] consulship to have been troubling, since it would not have been granted to him in such an illegal way if the city had been flourishing (55.4-5).

Pompey, it seems, was at a stage in his life when he should have been playing the role of an elder statesman, with his attention turned toward the forum and his contest with Caesar. Therefore Plutarch faults him not for loving his wives but for contracting the marriages at the wrong time. ${ }^{23}$ Pompey thus

21 Plutarch may have believed that Pompey was about forty-seven years old at this time, since in describing the triumph of $61 \mathrm{BC}$, he wrote that Pompey was "nearly forty" when in fact he was forty-five (Pomp. 46.1). See Nikolaidis, 50 n. 89, for instances of similar criticism of men in other Lives.

22 Though the phrase voũv $\mathscr{E} \chi \chi \varepsilon ı$ does not appear, Plutarch writes that Cornelia spent time among philosophers, as Porcia claimed to have done, and that she studied literature, geometry, and the lyre.

23 Nikolaidis, 75, sees Plutarch as making an allowance for Pompey's advanced age in his marriages to both Julia and Cornelia due to "his exceptional attractiveness and his 
distinguishes himself from Brutus, who did not withdraw from the conspiracy to spend time with Porcia but instead found that she could support him in his extra-household activities. We might conclude, then, that after a marriage achieves philia and virtue through eros, the husband is able to devote his attention to his civic responsibilities. Although this point was not made in the Amatorius, which focused on the nature of the relationship itself, it is perhaps implied in Hesiod's rule and in a general assumption about how an engaged citizen should interact with the community once he has established the proper environment in his home. ${ }^{24}$ In any case, Pompey's marriages come very close to meeting the high ideals of Plutarch's moral essay. In the way they fall short, they reinforce the two-pronged argument of the Amatorius: a good marriage must be contracted between two sensible, capable individuals at the right stage of life, and it must be bound together by ties of mutual erotic attraction, which in turn foster philia and virtue. ${ }^{25}$

\section{Bibliography}

Beneker, J. (2005), "Plutarch on the Rise and Fall of Pompey", in A. Pérez Jiménez and F. B. Titchener (edd.), Historical and Biographical Values of Plutarch's Works: Studies Devoted to Professor Philip Stadter by the International Plutarch Society, Málaga and Logan: 33-46.

Blomqvist, Karin (1997), "From Olympias to Aretaphila: Women in Politics in Plutarch", in Judith M. Mossman (ed.), Plutarch and his Intellectual World, London: $73-98$.

Brenk, F. E. (1988), "Plutarch's Erotikos: The Drag Down Pulled Up", ICS 13.2: $457-471$.

(2000). "All for Love: The Rhetoric of Exaggeration in Plutarch's Erotikos", in L. Van der Stockt (ed.), Rhetorical Theory and Praxis in Plutarch: Acta of the IVth International Congress of the International Plutarch Society, Leuven, July 3-6, 1996, Louvain: 4560.

Castellani, V. (2002), "Plutarch's 'Roman' Women”, in E. N. Ostenfeld (ed.), Greek Romans and Roman Greeks, Aarhus: 142-155.

Crawford, M. B. (1999), "Amatorius: Plutarch's Platonic Departure from the Peri Gamou Literature", in A. Pérez Jiménez, J. García López and Rosa M. Aguilar (edd.), Plutarco, Platón y Aristóteles, Actas Del V Congreso Internacional de la I.P.S. (Madrid-Cuenca, 4-7 De Mayo De 1999), Madrid: 287-297.

Dover, K. J. (1975), Greek Popular Morality in the Time of Plato and Aristotle, Oxford.

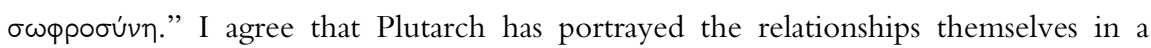
sympathetic manner, but I also read an overt criticism of how Pompey allowed these marriages to distract him from more important matters. See Beneker, 38-42, for a fuller argument.

24 See Wohl, 185-89, on the Coniugalia praecepta and the relationship between a man's management of his household and his political career.

25 I am very grateful to Tim Duff, Philip Stadter, and Georgia Tsouvala for reading drafts of this paper and offering many helpful suggestions. 
Einarson, B. (1954), review of R. Flacelière, Plutarque: Dialogue sur l'Amour (Eroticos) (Paris 1952), CPh 49.4: 278-279.

Flacelière, R. and E. Chambry (1978), Plutarque: Vies XIV, Dion - Brutus, Paris.

Flacelière, R. and M. Cuvigny (1980), Plutarque: Dialogue sur l'amour, Histoires d'amour, Paris.

Goldhill, S. (1995), Foucault's Virginity: Ancient Erotic Fiction and the History of Sexuality, Cambridge.

Helmbold, W. C. (1961), Plutarch: Moralia, IX (Loeb), Cambridge, Mass.

Martin, H. (1978), “Amatorius (Moralia 748E-771E)", in H. D. Betz (ed.), Plutarch's Ethical Writings and Early Christian Literature, Leiden: 442-537.

(1984), "Plutarch, Plato, and Eros", CB 60: 82-88.

McInerney, J. (2003), "Plutarch's Manly Women", in R. M. Rosen and I. Sluiter (edd.), Andreia: Studies in Manliness and Courage in Classical Antiquity, (Mnemosyne suppl. 238), Leiden and Boston: 319-344.

McNamara, Jo Ann (1999), "Gendering Virtue”, in Sarah B. Pomeroy (ed.), Plutarch's Advice to the Bride and Groom and A Consolation to His Wife, Oxford: 151-161.

Nikolaidis, A. G. (1997), "Plutarch on Women and Marriage", WS 110: 27-88.

Patterson, Cynthia (1999), "Plutarch's Advice to the Bride and Groom: Traditional Wisdom through a Philosophic Lens", in Pomeroy (ed.), 128-37.

Pelling, C. (1988), Plutarch: Life of Antony, Cambridge.

Perrin, B. (1918), Plutarch: Lives, VI (Loeb): Dion and Brutus, Timoleon and Aemilius Paulus, Cambridge, Mass.

Pomeroy, Sarah B. [ed.] (1999), Plutarch's Advice to the Bride and Groom and A Consolation to his Wife, Oxford.

Rist, J. M. (2001), "Plutarch's Amatorius: A Commentary on Plato's Theories of Love?", CQ 51.2: 557-575.

Russell, D. A. (1993), Plutarch: Selected Essays and Dialogues, Oxford.

Scott-Kilvert, I. (1965), Plutarch: Makers of Rome, London.

Stadter, P. A. (1999), "Philosophos kai Philandros: Plutarch's View of Women in the Moralia and Lives", in Pomeroy (ed.), 173-182.

Walcot, P. (1999), "Plutarch on Women", Symbolae Osloenses 74: 163-183.

West, M. L. (1978), Hesiod: Works \& Days, Oxford.

Whitmarsh, T. (2000), review of Pomeroy (ed.) above, Bryn Mawr Classical Review $2000,20.22$.

Wohl, Victoria (1997), "Scenes from a Marriage: Love and Logos in Plutarch's Coniugalia praecepta", Helios 24.2: 170-192. 